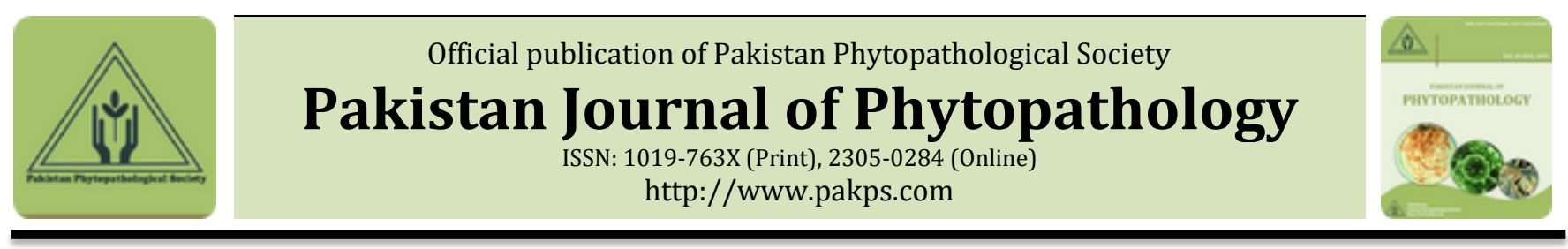

\title{
EVALUATION OF AVAILABLE GENETIC RESOURCE AGAINST BACTERIAL BLIGHT OF COTTON IN PAKISTAN
}

\author{
${ }^{a}$ Muhammad Sajid*, bAbdul Rashid, cMuhammad R. Bashir, ${ }^{\mathrm{d}}$ Muhammad A. Zeeshan, ${ }^{\mathrm{a}}$ Muhammad Abid, \\ a Rashida Parveen, aSobia Chohan, ${ }^{\text {Humaira Jamil }}$ \\ ${ }^{a}$ Department of Plant Pathology, Bahauddin Zakariya University Multan, Pakistan. \\ ${ }^{b}$ Department of Plant Pathology, University of Agriculture, Faisalabad, (ORIC), Pakistan. \\ 'Oilseeds Research Institute, Ayub Agriculture Research Institute Faisalabad, Pakistan. \\ ${ }^{d}$ Department of Plant Pathology, University College of Agriculture, University of Sargodha, Sargodha-40100, Pakistan. \\ eDepartment of Plant Breeding and Genetics, University of Agriculture, Faisalabad, Pakistan.
}

\section{A B S T R A C T}

Bacterial leaf Blight of cotton a major seed borne foliar disease that attacks the crop at all growth stages leading to cause severe losses in conducive environment. To find out best source of resistance against pathogen this research was conducted in the field area Department of Plant Pathology, University of Agriculture Faisalabad. Incidence of bacterial blight of cotton was determined on twenty eight varieties/advanced lines sown in field to determine the resistance resource against the disease. Two years data showed that seventeen varieties (BT-Z-33, BT-S-78, BT-786, BT-A-ONE, BT -282, BT-886, BT-3701, BT-SPECIAL, BT-802, Non Bt-FH 901, BT-92, BT-131, BT-905, BT-SUPPER, Non Bt-MNH 496, Non Bt-FH 1000, and BT-121) expressed moderately resistant response with 21-50\% disease incidence (rating 4). Five varieties viz. Non Bt-FH 207, Non BT-N 112, Non BT-FH 942, Non BT-MNH 6070 and Non Bt-FH 941 exhibited moderately susceptible response with $51-70 \%$ disease incidence under rating 5 . Four varieties namely Non BT-N 814, Non Bt-FH 900, Non BT-ANMOL and Non Bt-FH 2015 showed susceptible response with 71-80\% disease incidence (rating 6) while Non BT-REDACOLA and Non BT-C 26 expressed highly susceptible response with disease incidence $81-100 \%$ rating 7 against bacterial blight disease of cotton. Results indicate that a wide range of resistant resource is present in Pakistan against the disease. The selection of diverse germplasm/resistant varieties through screening is the most efficient, environment friendly and economical management strategy for farmers against this disease.

Keywords: Bacterial blight of cotton, Xanthomonas citri pv. malvacearum Screening, resistant germplasm

\section{INTRODUCTION}

Cotton (Gossipium hirsutum L.) belong to malvaceae family is the backbone of national economy of Pakistan contributing $6.9 \%$ to the value added in agriculture and upto1.4\% of GDP (GOP, 2011). Its present area, production and yield in the world showed that Pakistan is the fourth largest producer of cotton after China, USA and India (Hanif and Jafri, 2008). Cotton yield is influenced by numerous biotic and abiotic factors which enhance and causes several diseases of cotton. Among those diseases bacterial

* Corresponding Author:

Email: sajid1694@gmail.com

(C) 2017 Pak. J. Phytopathol. All rights reserved. blight is a potential threat to the cotton caused by Xanthomonas citri pv. malvacearum $(\mathrm{Xcm})$ (Vauterin et al., 2000). Yield losses due to bacterial blight of cotton depend upon the type of cultivars, age of the crop plant and type of infection (Mishra and Krishna, 2001). The extensive dissemination of pathogen and high variability made its control more difficult (Kamal and Naim, 1983). The bacterium could survive in the field on debris of previously harvested crops and its initial inoculum was seed borne (Mohan, 1983). Viable propagules of $X \mathrm{~cm}$ can also be recovered from cotton seed even after the storage for more than two years at $5^{\circ} \mathrm{C}$. Studies reported that about $2 \%$ seed infection could lead to destructive 
epidemics within field (Mehta et al., 2005). The bacterium attaches to the cotton leaf surface, enters in leaves through open stomata or wounds and develops symptoms in susceptible plants such as leaves and bracts 'Angular leaf spot' dark green, water soaked, angular lesions of 1 to $5 \mathrm{~mm}$ across especially obvious on the undersurface of leaves. Sometimes extensive dark green, water soaked lesions along the veins. Symptoms are usually more prevalent on lower leaves than on upper leaves. Lesions become dry and darken with the passage of time as well as leave fell down prematurely resulting in extensive defoliation. The best way to fight against the disease is the use of the resistant cultivars (Iglesias et al., 2010; Jacobs et al., 2010). It is the most efficient and eco-friendly method for the management of bacterial blight of cotton. Use of resistant varieties is commercial method because this method is done generally for the management of disease because it makes possible to avoid other management strategies like acid-delinting of seed, use of chemicals and the destruction of diseased plant residues followed by tillage operations (Thaxton and El-Zik, 2001; Turkkan and Dolar, 2009). The experiment was carried out to find out source of resistant against bacterial blight of cotton from existing varieties under natural field conditions. The findings can provide us the better alternate to the pesticides against this disease.

Table 1. Brinkerhoff disease rating scale for recording bacterial blight of cotton (1977).

\begin{tabular}{llll}
\hline Sr\# & Disease incidence (\%) & Description & Response \\
\hline 1 & 0 & Immune & $\mathrm{I}$ \\
\hline 2 & $1-10$ & Highly Resistant & HR \\
\hline 3 & $11-20$ & Resistant & $\mathrm{R}$ \\
\hline 4 & $21-50$ & Moderately Resistant & $\mathrm{MR}$ \\
\hline 5 & $51-70$ & Moderately Susceptible & $\mathrm{MS}$ \\
\hline 6 & $71-80$ & Susceptible & $\mathrm{S}$ \\
\hline 7 & $<80 \%$ & Highly Susceptible & HS \\
\hline
\end{tabular}

While disease incidence was calculated by using following formula.

$$
\text { Disease incidence }(\%)=\frac{\text { No. of infected plants }}{\text { Total No. of plants }} \times 100
$$

\section{STATISTICAL ANALYSIS}

The collected data of was subjected to analysis of variance (ANOVA) using (SAS® 2002). Means were compared by using the Fisher's least significant differences (LSD) at $(P=0.05)$.

\section{MATERIALS AND METHODS}

Evaluation of Cotton Germplasm: For the establishment of disease screening nursery, to find out source of resistance against bacterial blight disease of cotton, Seeds of 28 cotton varieties were collected from Ayub Agricultural Research Institute (AARI) Faisalabad, Central Cotton Research Institute (CCRI) Multan and Department of Plant Breeding and Genetics (PBG) University of Agriculture Faisalabad (UAF). Seed were sown in the research area of Plant Pathology UAF during the season of April 2011 and 2012. Sowing was done through dibbler method (Islam et al., 2001) by maintaining distance of $\mathrm{R} \times \mathrm{R}=30 \mathrm{~cm}$ and $\mathrm{P} \times \mathrm{P}=75 \mathrm{~cm}$ respectively. The seed of advanced cotton lines/verities were neither treated with chemical nor given any acid delinting chemical/material to increase chances of primary infection of the disease. Each variety was replicated three times under Randomized Completed Block Design (RCBD). No artificial inoculum was applied for initiation of infection. A line of highly susceptible variety i.e. S-12 was sown after every three entries as a spreader to make the most of the inoculum density under natural conditions whereas all agronomic practices including recommended dose of fertilizers, hoeing and irrigation schedule were followed to keep the crop in good condition. Data regarding disease incidence was collected on weekly basis by using Brinkerhoff (1977) disease rating scale (Table 1). 
observed that ratio of disease incidence was more in Non Bt varieties as compared to Bt. Twenty eight germplasm of cotton were appraised against bacterial blight of cotton for two years under field conditions. During 2011 seventeen varieties i.e. BT-Z-33(25.36), BT-S-78(25.80), BT-786(28.60), BT-A-ONE(28.80), BT -282(30.50), BT-886(33.50), BT3701(38.30), BT-SPECIAL(38.40), BT-802(41.30), Non Bt-FH 901(41.70), BT-92(41.70), BT-131(43.80), BT-905(44.60), BT-SUPPER(45.40), Non Bt-MNH 496(47.60), Non Bt-FH 1000(48.60) and BT-121(48.60) percent disease incidence expressed moderately resistant response with rating 4 . Five varieties viz. Non Bt-FH 207 (54.50), Non BT-N 112 (54.70), Non BT-FH 942, Non BT-MNH 6070 (61.50) and Non Bt-FH 941 (63.40) percent disease incidence exhibited moderately susceptible response under rating 5 . Four varieties namely Non BT-N 814, Non Bt-FH 900, Non BT-ANMOL and Non BtFH 2015 showed susceptible response with (70.40) (74.70) (74.80) and (78.50) percent disease incidence (rating 6) whereas two varieties i.e. Non BT-REDACOLA and Non BT-C 26 expressed highly susceptible response with 81.50 and
83.50 percent disease incidence with rating 7 during 2011 (Table 2 \& Figure 1). Similarly, during 2012, BT-Z-33(22.20), BT-S-78(26.50), BT-786(26.70), BT-A-ONE(27.60), BT 282(31.50), BT-886(34.60), BT-3701(35.30), BTSPECIAL(36.80), BT-802(41.70), Non Bt-FH 901(42.30), BT92(43.40), BT-131(43.40), BT-905(44.40), BTSUPPER(46.80), Non Bt-MNH 496(49.50), Non Bt-FH 1000(51.20) and BT-121(52.40) percent disease incidence, showed moderately resistance response with rating 4. Whereas five varieties i.e. Non Bt-FH 207 (56.30), Non BT-N 112 (57.50), Non BT-FH 942 (59.50), Non BT-MNH 6070 (61.60) and Non Bt-FH 941(64.70) exhibited moderately susceptible response with rating 5. Four varieties naming Non BT-N 814 (71.26), Non Bt-FH 900 (78.80), Non BTANMOL (77.40) and Non Bt-FH 2015 (79.60) showed susceptible response with rating 6. Only two varieties Non BT-REDACOLA (80.60) and Non BT-C 26 with (85.60) percent disease incidence exhibited highly susceptible response with rating 7 during the year of 2012. (Table 3 \& Figure 2).

Table 2. Response of cotton varieties against bacterial blight under field conditions during 2011.

\begin{tabular}{|c|c|c|c|c|}
\hline Sr.\# & Varieties/Lines & Disease rating & Disease incidence (\%) & Response \\
\hline 1 & BT-Z-33 & 4 & $25.36 \mathrm{~T}$ & MR \\
\hline 2 & BT-S-78 & 4 & $25.80 \mathrm{~T}$ & MR \\
\hline 3 & BT-786 & 4 & $28.60 \mathrm{~S}$ & MR \\
\hline 4 & BT-A-ONE & 4 & $28.80 \mathrm{~S}$ & MR \\
\hline 5 & BT -282 & 4 & $30.50 \mathrm{R}$ & MR \\
\hline 6 & BT-886 & 4 & $33.50 \mathrm{Q}$ & MR \\
\hline 7 & BT-3701 & 4 & $38.30 \mathrm{P}$ & MR \\
\hline 8 & BT-SPECIAL & 4 & $38.40 \mathrm{P}$ & MR \\
\hline 9 & BT-802 & 4 & 41.300 & MR \\
\hline 10 & Non Bt-FH 901 & 4 & 41.700 & MR \\
\hline 11 & BT-92 & 4 & 41.700 & MR \\
\hline 12 & BT-131 & 4 & $43.80 \mathrm{~N}$ & MR \\
\hline 13 & BT-905 & 4 & $44.60 \mathrm{M}$ & MR \\
\hline 14 & BT-SUPPER & 4 & $45.40 \mathrm{~L}$ & MR \\
\hline 15 & Non Bt-MNH 496 & 4 & $47.60 \mathrm{~K}$ & MR \\
\hline 16 & Non Bt-FH 1000 & 4 & $48.60 \mathrm{~J}$ & MR \\
\hline 17 & BT-121 & 4 & $48.60 \mathrm{~J}$ & MR \\
\hline 18 & Non Bt-FH 207 & 5 & $54.50 \mathrm{I}$ & MS \\
\hline 19 & Non BT-N 112 & 5 & $54.70 \mathrm{I}$ & MS \\
\hline 20 & Non BT-FH 942 & 5 & $55.70 \mathrm{H}$ & MS \\
\hline 21 & Non BT-MNH 6070 & 5 & $61.50 \mathrm{G}$ & MS \\
\hline 22 & Non Bt-FH 941 & 5 & $63.40 \mathrm{~F}$ & MS \\
\hline 23 & Non BT-N 814 & 6 & $70.40 \mathrm{E}$ & $\mathrm{S}$ \\
\hline 24 & Non Bt-FH 900 & 6 & $74.70 \mathrm{D}$ & $\mathrm{S}$ \\
\hline 25 & Non BT-ANMOL & 6 & $74.80 \mathrm{D}$ & $\mathrm{S}$ \\
\hline 26 & Non Bt-FH 2015 & 6 & $78.50 \mathrm{C}$ & $\mathrm{S}$ \\
\hline 27 & Non BT-REDACOLA & 7 & $81.50 \mathrm{~B}$ & $\mathrm{HS}$ \\
\hline 28 & Non BT-C 26 & 7 & $83.50 \mathrm{~A}$ & HS \\
\hline
\end{tabular}

${ }^{*}$ Mean values in a column sharing similar letters do not differ significantly as determined by the LSD test (P $\left.\leq 0.05\right)$.

$\mathrm{MR}=$ Moderately resistant, $\mathrm{MS}=$ Moderately susceptible $\mathrm{S}=$ Susceptible, $\mathrm{HS}=$ Highly susceptible 
Pak. J. Phytopathol., Vol. 29 (01) 2017. 63-68

Table 3. Response of cotton varieties against bacterial blight under field conditions during 2012.

\begin{tabular}{ccccc}
\hline Sr.\# & Varieties/Lines & Disease rating & Disease incidence (\%) & Response \\
\hline 1 & BT-Z-33 & 4 & $22.20 \mathrm{a}$ & MR \\
\hline 2 & BT-S-78 & 4 & $26.50 \mathrm{Z}$ & $\mathrm{MR}$ \\
\hline 3 & BT-786 & 4 & $26.70 \mathrm{Y}$ & $\mathrm{MR}$ \\
\hline 4 & BT-A-ONE & 4 & $27.60 \mathrm{X}$ & $\mathrm{MR}$ \\
\hline 5 & BT-282 & 4 & $31.50 \mathrm{~W}$ & $\mathrm{MR}$ \\
\hline 6 & BT-886 & 4 & $34.60 \mathrm{~V}$ & $\mathrm{MR}$ \\
\hline 7 & BT-3701 & 4 & $35.30 \mathrm{U}$ & $\mathrm{MR}$ \\
\hline 8 & BT-SPECIAL & 4 & $36.80 \mathrm{~T}$ & $\mathrm{MR}$ \\
\hline 9 & BT-802 & 4 & $41.70 \mathrm{~S}$ & $\mathrm{MR}$ \\
\hline 10 & Non Bt-FH 901 & 4 & $42.30 \mathrm{R}$ & $\mathrm{MR}$ \\
\hline 11 & BT-92 & 4 & $43.40 \mathrm{Q}$ & $\mathrm{MR}$ \\
\hline 12 & BT-131 & 4 & $43.40 \mathrm{Q}$ & $\mathrm{MR}$ \\
\hline 13 & BT-905 & 4 & $44.40 \mathrm{P}$ & $\mathrm{MR}$ \\
\hline 14 & BT-SUPPER & 4 & $46.80 \mathrm{O}$ & $\mathrm{MR}$ \\
\hline 15 & Non Bt-MNH 496 & 4 & $49.50 \mathrm{~N}$ & $\mathrm{MR}$ \\
\hline 16 & Non Bt-FH 1000 & $51.20 \mathrm{M}$ & $\mathrm{MR}$ \\
\hline 17 & BT-121 & 4 & $52.40 \mathrm{~L}$ & $\mathrm{MR}$ \\
\hline 18 & Non Bt-FH 207 & 4 & $56.30 \mathrm{~K}$ & $\mathrm{MS}$ \\
\hline 19 & Non BT-N 112 & 5 & $57.50 \mathrm{~J}$ & $\mathrm{MS}$ \\
\hline 20 & Non BT-FH 942 & 5 & $59.50 \mathrm{I}$ & $\mathrm{MS}$ \\
\hline 21 & Non BT-MNH 6070 & $61.60 \mathrm{H}$ & $\mathrm{MS}$ \\
\hline 22 & Non Bt-FH 941 & 5 & $64.70 \mathrm{G}$ & $\mathrm{MS}$ \\
\hline 23 & Non BT-N 814 & 5 & $71.26 \mathrm{~F}$ & $\mathrm{~S}$ \\
\hline 24 & Non Bt-FH 900 & 5 & $76.80 \mathrm{E}$ & $\mathrm{S}$ \\
\hline 25 & Non BT-ANMOL & 6 & $77.40 \mathrm{D}$ & $\mathrm{S}$ \\
\hline 26 & Non Bt-FH 2015 & 6 & $79.60 \mathrm{C}$ & $\mathrm{S}$ \\
\hline 27 & Non BT-REDACOLA & $60.60 \mathrm{~B}$ & HS \\
\hline 28 & Non BT-C 26 & 6 & $85.60 \mathrm{~A}$ & HS \\
\hline
\end{tabular}

*Mean values in a column sharing similar letters do not differ significantly as determined by the LSD test $(\mathrm{P} \leq 0.05)$.

MR = Moderately resistant, MS = Moderately susceptible, $\mathrm{S}=$ Susceptible, HS = Highly susceptible

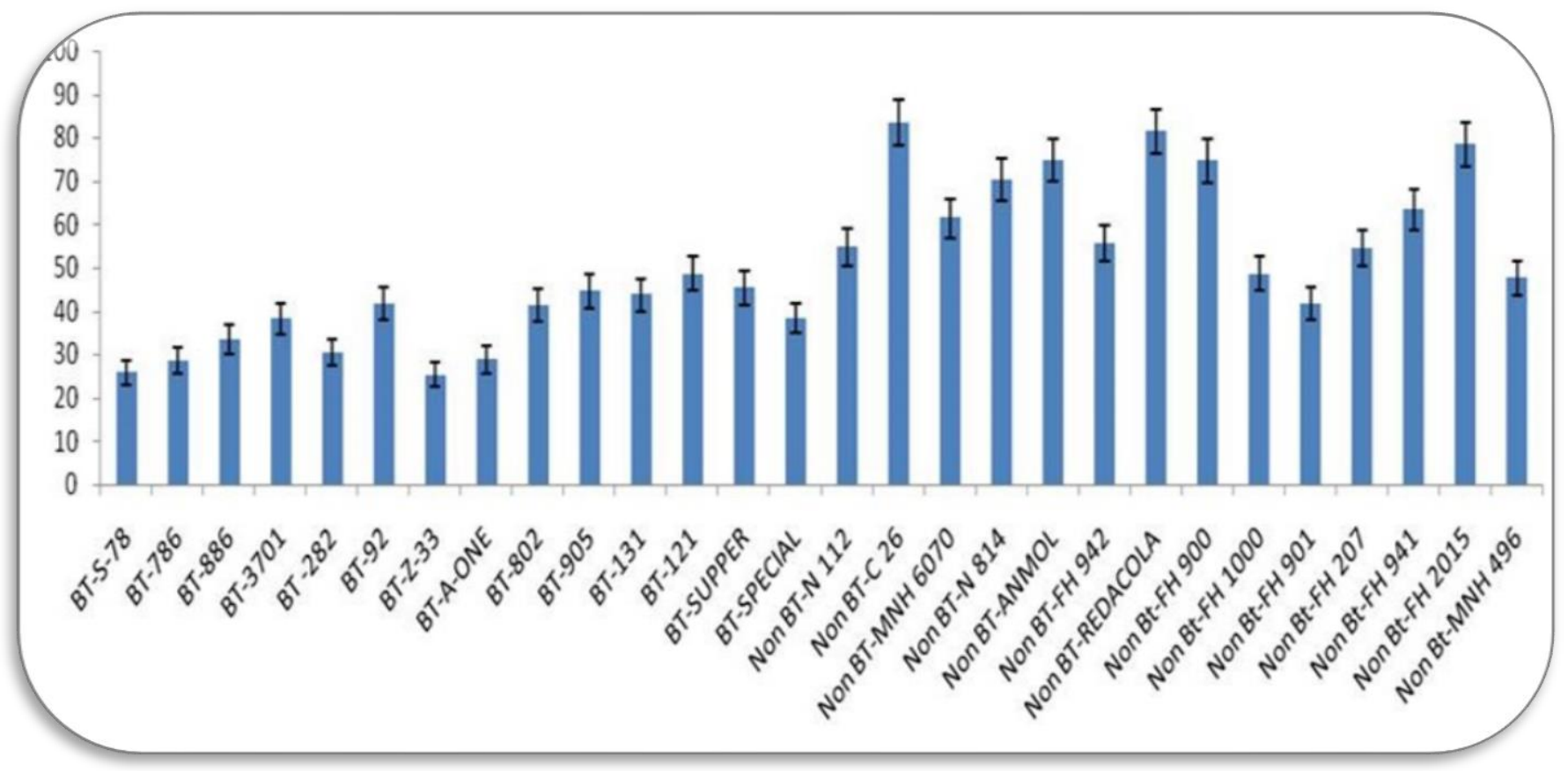

Figure 1. Response of cotton germplasm against Xanthomonas citri pv. malvacearum in field conditions during 2011. 


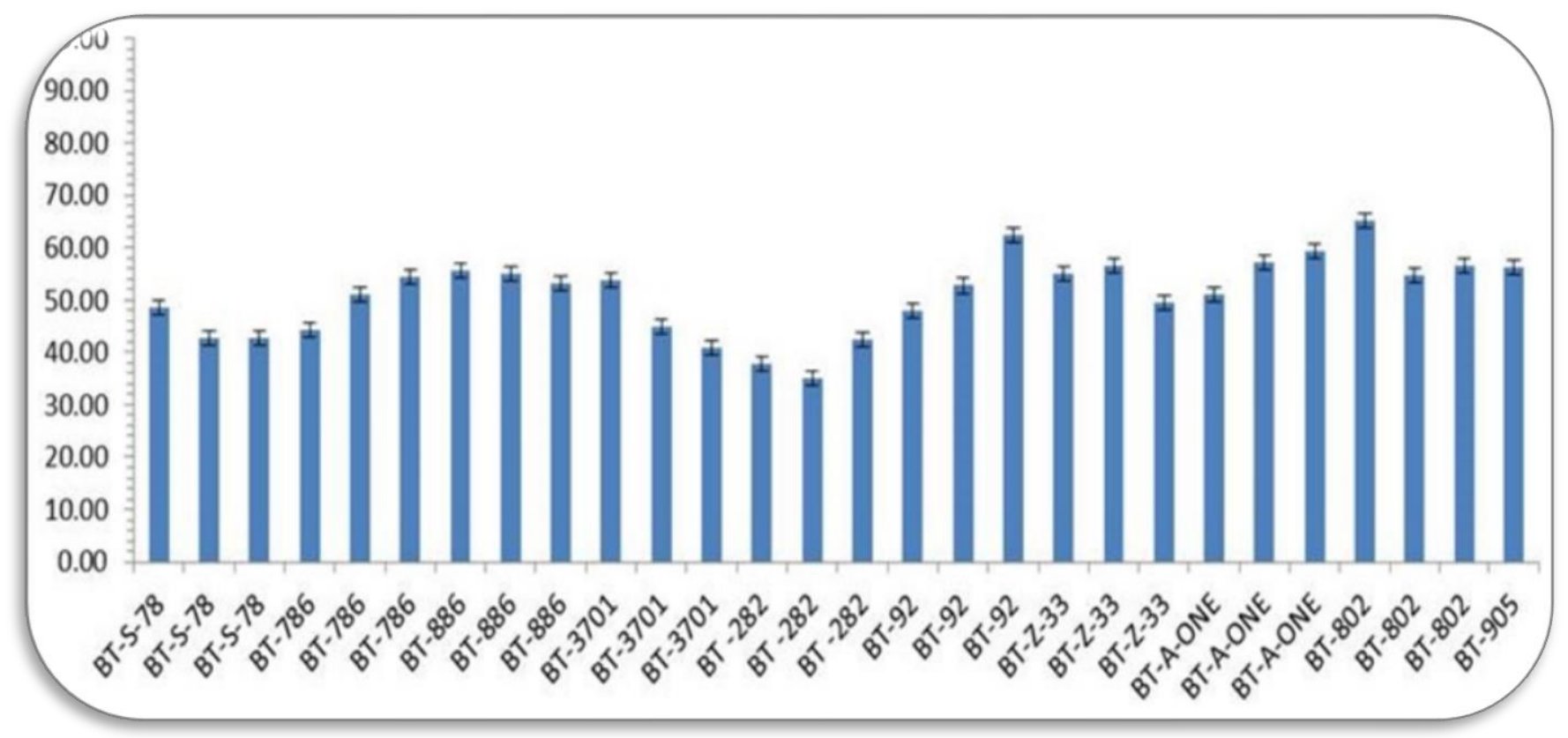

Figure 2. Response of cotton germplasm against Xanthomonas citri pv. malvacearum in field conditions during 2011.

\section{DISCUSSION}

Symptomology of a disease plays an imperative role in the expected of altered physiological changes and the establishment of pathogen on host. There are several factors i.e. plant age, infection time, type of infection, strain of bacteria and genetic makeup of the host plant and very important the role of environmental conditions which plays key part for the development of disease. Heavy losses in yield occurred on early infection of disease. To escape disease establishment screening of available germplasm is short term and easy method to get resistant varieties. That is why in present study, twenty eight varieties were evaluated against bacterial blight of cotton under field conditions for two years (2011 and 2012). During both years seventeen varieties/advanced lines i.e. BT-Z-33, BT-S-78, BT-786, BT-A-ONE, BT -282, BT-886, BT-3701, BT-SPECIALBT802Non Bt-FH 901BT-92BT-131, BT-905, BT-SUPPER, Non Bt-MNH 496, Non Bt-FH 1000 and BT-121 expressed moderately resistant response with rating 4 while five varieties Non Bt-FH 207, Non BT-N 112, Non BT-FH 942, Non BT-MNH 6070 and Non Bt-FH 941 exhibited moderately susceptible response under rating 5. While four varieties namely Non BT-N 814, Non Bt-FH 900, Non BT-ANMOL and Non Bt-FH 2015 showed susceptible response (rating 6) whereas two varieties i.e. Non BT-REDACOLA and Non BT-C 26 expressed highly susceptible response with rating 7. Outcomes of the present study are also supported by the work of (Atiq et al., 2014) that tested fifteen cotton germplasm to govern their genetic response. Results showed that none of variety/advanced line showed immune or highly resistant response although FH-14, Bt-121 and SLH-336 expressed moderately resistance whereas Kirn, SLH Bt6, Bt-666, CIM-595, FH-113 and Bt-MK2 showed moderately susceptible and SG-1, Bt-222, Bt-457, Bt-7, SLH-317 and Bt-986 showed highly susceptible response against the bacterial blight disease of cotton. Drishak et al., (2014) screened out cotton varieties by using diverse inoculation techniques and found that no variety expressed highly resistant response.

As the result of present study, the selected resistant varieties can be used in breeding program as source of resistance against bacterial blight and if these resistant varieties possess all required agronomic characteristics then these can also be introduced at commercial level.

\section{REFERENCES}

Atiq, M., W. Ahmad, M. Rafique, S. T. Sahi, A. Rehman, M. Younis, M. Shafiq, K. Ahmad, T. M. Ahmad and U. Nawaz. 2014. Genetic potential of cotton germplasm for management of bacterial blight disease. Pak. J. of Phytopathol. 26 (1): 109-112.

Brinkerhoff L. A. 1977. Bacterial blight of cotton. FAO Consultant Report of Pakistan 73/026. Submitted to FAO (UNO). Rome. pp.11.

Drishak, K. U., S. A. H. Naqvi, R. Perveen, U. Atif 2014. Studies on Isolation, Identification and assessment of bacterial blight of cotton through 
Pak. J. Phytopathol., Vol. 29 (01) 2017. 63-68

some dispersal mechanism of Xanthomonas axonopodis pv. malvacearum. Inter. J. of Bio. Sci. 06: 36-45.

GOP. 2011. Pakistan Economic Survey. Economic Advisor's Wing, Finance Division, Islamabad. Government of Pakistan.

Hanif M. N., S. K. Jafri. 2008. Financial Development and Textile Sector Competitiveness. A case study of Pakistan. State Bank of Pakistan Working Paper Series No. 20.

Iglesias, I., O. Escuredo, C. Seijo. and J. Méndez. 2010. Phytophthora infestans prediction for a potato crop. Am. J. Potato Res. 87: 32-40.

Islam., Shahidul, and K. Sharmin. 2001. Seasonal fluctuations of carbohydrate accumulation and metabolism of three tomato (Lycopersicon esculentum Mill.) cultivars grown at seven sowing times. The J. of Horti. Sci. and Biotechnol. 76(6): 764-770.

Jacobs, M. M. J., B. Vosman, V. G. A. A. Vleeshouwers, R. G. F. Visser, B. Henken and R. G. V. Berg. 2010. A novel approach to locate Phytophthora infestans resistance genes on the potato genetic map. Theor. Appl. Genet. 120: 785-796.
Kamal, M. and Q. M. Naim. 1983. Final report of the scheme on investigation of boll rot of cotton. Agri. Res. Inst. Tandojam pp. 20.

Mehta, Y. R., C. Bomfeti. and V. Bolognini. 2005. A semi selective agar medium to detect the presence of Xanthomonas citri pv. malvacearum in naturally infected cotton seed. Fitopatol. Bras. 30: 5.

Mishra, S. P. and A. Krishna. 2001. Assessment of yield losses due to bacterial blight in cotton. J. of Mycol. and Pl. Pathol. 31(2): 232-233.

Mohan, S. K. 1983. Seed transmission and epidemiology of Xanthamonas campestris pv. malvacearum. Seed Sci. Technol. 11: 569-571.

Thaxton, P. M. and K. M. E. Zik. 2001. Bacterial blight. pp. 34-35. In: T. L. Kirkpatrick and C. S. Rothrock (ed.) Compendium of cotton diseases. 2nd ed. Am. Phytopathol. Soc. St. Paul, MN.

Turkkan, M., and F. S. Dolar. 2009. Determination of pathogenic variability of Didymella rabiei the agent of ascochyta blight of chickpea in Turkey. Turk. J. of Agri. and Forest. 33: 685-591.

Vauterin, L., J. Rademaker and J. Swings. 2000. Synopsis of the taxonomy of the genus Xanthomonas. Phtyopathol. 90: 677-682. 